er en rigtig god idé, og den fungerer glimrende. Lassen påviser kort de problemer, der er med Sløks renæssancesyn - først og fremmest at opfatte epoken som et unikt brud - og viser derefter, hvordan hans enkelte pointer og analyser kan transporteres over $i$ en mere moderne historieopfattelse. Teksten er god og er nok en mere produktiv måde at bruge Sløk som idéhistoriker end fx Amdisens bud.

Som et coda er der indføjet et ganske fint interview med Sløk, som man kan håbe inspirerer folk til at stifte nærmere bekendtskab med mandens tænkning. Derefter følger en bibliografi, der forlænger den, der blev samlet i 1986 til festskriftet Sprogets Mesterskab, samt en fortegnelse over Sløks undervisning på idéhistorie. Begge dele er fremragende redskaber. Undervisningsfortegnelsen afslører i hvor høj grad, faget idéhistorie stadig er tegnet af 'arven fra Sløk'. De fleste discipliner, der eksisterer på faget i dag, kan føres direkte tilbage til specifikke undervisningsforløb afholdt af Sløk.

Alt $\mathrm{i}$ alt en læseværdig antologi. Især Jens Viggo Nielsens bidrag gør bogen uomgængelig for den begyndende Sløk-læser/forsker, hvilket jo må have været målet. Det er selvfølgelig ærgerligt, at det ikke er en entydigt fantastisk antologi, når nu den skal skabe en eksplosion i interessen for den gamle professor, men forhåbentlig vil de bedre af bidragene inspirere til flere forskningsprojekter i forbindelse med Johannes Sløk.

Mikkel Lodahl

\section{Det globale civilsamfund}

Jobn Keane: Det globale civilsamfund. Forlaget Klim, 2005, 297 sider, kr. 298,-

Det globale civilsamfund er endnu et bidrag til den store debat om, hvorledes den aktuelle globale udvikling, eller i det mindste et vigtigt aspekt af den, bør forstås. Denne bog er et forsøg på at komme med "et bidrag til feltet for anvendt politisk filosofi, som en lille gave til alle dem, der er interesseret i ideers praktiske betydning" (s. 10). Nærmest et idéhistorisk program. Et af bogens mål er at undersøge de historiske rødder for begrebet om det globale civilsamfund "og analysere dens aktuelle betydninger, anvendelse og fremtidige politiske potentiale" (s. 9). Disse mål søger Keane at nå ved at inddrage en lang række samfundsvidenskabelige og humanistiske discipliner; bl.a. antropologi, international politik, samtidshistorie, sociologi, økonomi og filosofi.

En spændende udfordring ved arbejdet med det globale civilsamfund er, at der ifølge Keane er tale om, at det globale civilsamfund ikke er et færdigt foreliggende objekt, men et "subjekt undervejs" eller "et ufærdigt projekt" (s. 22). Det virker rigtigt når Keane hævder, at en forståelse af det globale civilsamfund kan "forbedre vores forståelse af den gryende planetariske orden" (s. 38).

Keane peger på, at med civilsamfundet "som [med] alle andre begreber med en politisk kant er dets betydning hverken selvindlysende 
eller automatisk fordomsfri" (s. 15). Keane søger i sin tilgang til det globale civilsamfund at undgå, hvad han ser som en udbredt kilde til forvirring $i$ andre behandlinger af fænomenet; nemlig at blande forskellige aspekter ved behandlingen af begrebet. Heroverfor skelner han mellem tre forskellige niveauer. For det første opererer han med en analytisk-deskriptiv anvendelse, dernæst en strategisk politisk kalkulation og endelig en diskussion af det normative grundlag.

Keane bestemmer det globale civilsamfund som "et dynamisk ikekestatsligt system af gensidigt forbundne sociookonomiske institutioner, der spander over bele jorden ... Det indbefatter individer, husstande, profitsøgende virksomheder, ikke-statslige nonprofitorganisationer, koalitioner, sociale bevægelser, sproglige fællesskaber og kulturelle identiteter."(s. 23). Tæt under denne beskrivelses overflade ligger der et normativt grundlag for dette ufærdige projekt. Således ekskluderes kriminelle netværk og bærere af voldelige traditioner fra det globale civilsamfund, hvis væv de tværtimod ødelægger. Det globale civilsamfund "består af forskellige overlappende normer for ikke-voldelig høflighed ... det globale civilsamfund er kendetegnet af en stærk og altovervejende tendens til både at marginalisere og undgå brugen af vold.” (s. 28f). På den ene side er denne tilgang med til at sikre, at civilsamfundet ikke bliver til en skraldespandskategori, men på den anden side er der også tale om en indsmugling af normative elementer i bestemmelsen af begrebet. Keane undgår til gengæld at ophøje vestlige standarder til at være universelle forbilleder for det globale civilsamfund og behandler impulser fra traditioner fra bl.a. islam og de antikoloniale bevægelser, som har peget frem mod mere civiliserede tilstande.

En af de bestemmelser af, hvad der hører til det globale civilsamfund, som er værd at fremhæve, er, at Keane ser virksomheder og marked som en del af det civile samfund. Dette står i modsætning til den opfattelse, som er mest udbredt i Danmark, nemlig at både marked og stat står overfor civilsamfundet. Denne inddragelse af markedet i civilsamfundets domæne gør dog ikke, at Keane er blind for, at der i civilsamfundet også findes kapitalismekritiske kræfter: "Institutioner som andelsvirksomheder og fagforeninger modvirkede den private kapitals magt" (s. 76). De bevægelser, som arbejder ud fra, at markedet står overfor civilsamfundet, betegner Keane som puritanister i forhold til civilsamfundet. Hvilket ikke er positivt ment. Deres perspektiv rummer ifølge Keane den svaghed, at det "negligerer markedet, konflikterne og volden og opfatter dette samfund som en behagelig og fredelig form for frivilligt samarbejde" (s. 11).

Et centralt argument for, at "den kunstige distinktion mellem 'markedet' og 'det globale civilsamfund' er uberettiget" (s. 118), er hos Keane, at civilsamfundet er afhængig af ek- 
sistensen af et marked og udvikles af 'turbo-kapitalismen'. På den anden side er markedet også afhængig af civilsamfund: "Inden for markedets rammer benytter de, der udfører deres forretninger og passer deres arbejde, sig af nogle iboende sociale kræfter. Deres aktiviteter er altid forankret i det civile samfunds møder, det 'smøres' af normer som punktlighed, tillid, ærlighed, pålidelighed, fælles forpligtelser og ikke-vold" (s. 111f). Efter min mening er argumentet for at skelne mellem marked og civilsamfund ud fra deres gensidige afhængighed svagt. Det samme kan siges om forholdet mellem stater og civilsamfund. Stater kan næppe eksistere uden et civilsamfund. Og desuden støtter stater ofte kræfter i civilsamfundet. Især det sidste har Keane da også blik for i såvel sine empiriske som strategiske overvejelser. Men her opretholdes der alligevel et teoretisk skel mellem de to størrelser.

Det forekommer mig, at der er et vægtigt argument for at holde markedet teoretisk adskilt fra civilsamfundet. Nemlig at den logik - profitmotivet - som markedet er styret af, er så specifik, at den udskiller sig afgørende fra det globale civilsamfund. Keane er også opmærksom på, at "det globale civilsamfund er konstant under pres fra markedets side" (s. 129).

I den afsluttende del af bogen diskuterer Keane muligheden af en fundering af det globale samfund som et normativt ideal. Argumentationer ud fra såvel naturrettigheder som menneskelig konsensus afvises. Dog uden at der gås i dybden med kritikken: "Denne kritik skal ikke opholde os her, fordi det er let at se, at alle de ovenforstående etiske legitimeringer af det globale civilsamfund er fejlagtige ... [lige som] filosofiens øvrige forsøg på at tilvejebringe et rationelt grundlag for etiske principper synes at være mislykkede" (s. 261). En noget let måde at komme uden om velbegrundede forsøg på at komme med rationelt begrundede universelle normer. Den amerikanske filosof Martha Nussbaum kommer efter min mening langt ved at tage udgangspunkt i nogle universelle menneskelige vilkår. Keane har større tillid til teologen Hans Künge, som mener, at "religion bringer sikkerhed til den etiske sfære ... Religion forsyner og velsigner etiske rettigheder og forpligtelser med dyb mening, med 'absoluthed og universalitet."' (s. 263) Künges argumenter omtales ligefrem som "jernhårde" (s. 262).

Keanes fornemmelse er, "at selvom mennesket ikke kan komme uden om fornuften, er fornuften alene ikke nok" (s. 262). Hans bud på, hvad man så kan sige, er bl.a. at "civilsamfundets moral er at bekæmpe fordomme, arrogance og had" (s. 268). Dette er ifølge Keane ikke at forstå som en universelt gyldig norm. Keane gentager en gammel traver om, at det at opfatte ens eget synspunkt som sandt med nødvendighed fører til totalitarisme og overgreb. Dette har i lang tid forekommet mig at være et syns- 
punkt, som overser en ret simpel indvending: At konsekvensen af at tro at man har fundet sandheden, afhænger af indholdet af denne sandhed. Nogen kunne for eksempel tro på sandheden af værdier som demokrati, individernes rettighed til fri udfoldelse og tolerance, som uomgængelige elementer af det gode samfund. At de, der mener at sidde inde med sådanne sandheder, skulle være disponerede for totalitarisme og voldelige overgreb mod individer, har jeg svært ved at se. Hvilke politiske konsekvenser der er af at tro på universaliteten eller sandheden af sine normer må således afhænge af, hvilke sandheder der er tale om.

Selv om Keane ikke kommer med noget stærkt filosofisk argument giver han alligevel nogle bud på, hvad det globale civilsamfunds normer er: " Et muligt svar på spørgsmålet er at forstå det globale samfund - både teoretisk og i praksis - som en betingelse for muligheden for mangfoldige etikker, med andre ord som et univers med frihed fra en partikulær, universel etik" (s. 266). Han ser det som en forudsætning at deltagere i det globale civilsamfund indgår en slags kontrakt om "et universelt etisk princip, der garanterer respekt for deres moralske forskelle" (s. 274). Dette universelle princip er netop et forskellighedens eller 'uenighedens princip'. Hans opfattelse er, at det ikke er muligt at give en filosofisk begrundelse for dette princip - og han mener heller ikke, det er nødvendigt.
Bogen kan ses som en del af samfundsteoretiske værker fra forlaget Klim. De kendteste titler herfra er Naomi Kleins No Logo og Richard Floridas Den kreative klasse. På trods af Det globale civilsamfund's kvaliteter er det ganske forståligt, at den ikke har kunnet vække samme opmærksomhed. Dels er den ganske akademisk i sin form, dertil kommer, at der til tider er en mangel på skarphed i visse analyser og distinktioner. Som det er fremgået, synes jeg ikke, at Keane helt formår at holde sig til de adskillelser og afgrænsninger, han opregner. En klar styrke ved bogen er, at Keane formår at trække på eksempler uden for den vestlige kultur. Det har til tider karakter af krydderi, men det er et krydderi, som giver en mere afbalanceret helhed. Bogens styrke er en nuanceret fremstilling, især i de deskriptive og strategiske dele. For den, der arbejder med globaliseringsfænomener, kan der være en del at hente - ikke mindst på grund af den empiriske rigdom $\mathrm{i}$ fremstillingen.

Peter Bjorntoft

\section{Skiftespor}

Poul Ferland: Skiftespor - essays om Adornos tankning og tidens kultur. Bindslev, 2005, 142 sider, kr. 168,-

Essaysamlingen består af en række af tekster om Adorno og kulturkritik, som Poul Ferland har udgivet i forskellige sammenhænge i perioden 